\title{
APLIKASI TES BUTA WARNA DENGAN METODE FARNSWORTH MUNSELL BERBASIS ANDROID
}

\author{
Ardi Wijaya, S.Kom, M.Kom 1, Muntahanah, S.Kom,M.Kom2 \\ Program Studi Informatika, Fakultas Teknik, Universitas Muhammadiyah Bengkulu \\ Jl. Bali, Bengkulu 38119 \\ ardiwijaya@umb.ac.id \\ muntahanah@umb.ac.id
}

\begin{abstract}
Color blindness tests are currently needed by the industry, education and government. This is caused by human dependence on work or education which is closely related to color. One method of color blindness testing is the Farnsworth Munsell method. Farnsworth Munsell is a method to see someone's ability to arrange color brightness. This test can distinguish types of color vision deficiency and evaluate the severity of color discrimination. The Android operating system is currently the most widely used on smartphones and tablet computers. The application is built on an Android-based system with a minimum version of Android 4.4.4 (Kitkat). The purpose and benefits of this research are to build an android-based color blind test application by applying the Farnsworth Munsell method so that it can facilitate the general public in obtaining and using it and it is expected to get fairly accurate results. From the results of developing this application in accordance with the planning and testing results of the application system blackbox can run well without obstacles. The application can process the calculation of the Farnsworth Munsell method and produce output in accordance with the rules of the method. The color blind test application using the Farnsworth Munsell method can simplify the calculation of error scores automatically making it easier for users to get test results.

Keywords: Color blindness, Eye disorders, Eye test, Farnsworth Munsell Method, Android Application, Android operating system
\end{abstract}

Abstrak - Tes buta warna saat ini sangat dibutuhkan bagi dunia industri, pendidikan, maupun pemerintahan. Hal ini disebabkan oleh ketergantungan manusia dalam pekerjaan atau pendidikan yang erat sekali berhubungan dengan warna. Salah satu metode tes buta warna adalah metode Farnsworth Munsell. Farnsworth Munsell adalah metode untuk melihat kemampuan seseorang menyusun kecerahan warna. Tes ini dapat membedakan tipe defisiensi penglihatan warna dan mengevaluasi tingkat keparahan diskriminasi warna. Sistem operasi Android saat ini paling banyak digunakan pada smartphone dan komputer tablet. Aplikasi dibangun pada sistem berbasis Android dengan minimal versi Android 4.4.4 (Kitkat). Tujuan dan manfaat dari penelitian ini adalah ingin membangun sebuah aplikasi tes buta warna berbasis android dengan menerapkan metode Farnsworth Munsell sehingga dapat memudahkan kalangan umum dalam mendapatkan dan menggunakannya serta ini diharapkan dapat mendapatkan hasil yang cukup akurat. Dari hasil pengembangan aplikasi ini sesuai dengan perencanaan dan hasil pengujian blackbox sistem aplikasi dapat berjalan dengan baik tanpa kendala. Aplikasi dapat memproses perhitungan metode Farnsworth Munsell dan menghasilkan output yang sesuai dengan kaidah metode tersebut. Aplikasi tes buta warna menggunakan metode Farnsworth Munsell ini dapat mempermudah perhitungan skor error secara otomatis sehingga mempermudah pengguna dalam mendapatkan hasil tes.

Kata kunci: Buta warna, Kelainan mata, Tes mata, Metode Farnsworth Munsell, Aplikasi Android, Sistem operasi Android

\section{PENDAHULUAN}

Mata adalah indra manusia yang berfungsi sebagai alat penglihat. Mata merupakan alat penglihatan yang kompleks. Tidak hanya bola mata yang berperan agar kita dapat melihat alis, bulu mata, dan kelopak mata juga berperan penting dalam mendukung penglihatan. Sebagai alat penglihatan, indra ini juga dapat mengalami gangguan salah satunya adalah buta warna. Buta warna adalah suatu keadaan dimana seseorang tidak dapat membedakan warna tertentu yang bisa dibedakan oleh orang dengan mata normal. Seseorang yang menderita buta warna dapat disebabkan oleh penggunaan obat-obatan yang berlebihan kelainan atau kelainan sejak lahir.

Kemajuan ilmu pengetahuan di bidang kedokteran berdampak pada teknologi medis yang semakin canggih mampu mendiagnosis bahkan mengobati penyakit tertentu. Tes buta warna saat ini sangat dibutuhkan bagi dunia industri, pendidikan, maupun pemerintahan. Hal ini disebabkan oleh ketergantungan manusia dalam pekerjaan atau pendidikan yang erat 
sekali berhubungan dengan warna. Kelainan buta warna dapat mengganggu aktivitas penderitanya sehari-hari. Misalnya saja dalam membedakan warna pakaian, warna lampu lalu lintas saat berkendara, warna simbol-simbol tertentu dan lain sebagainya. Dalam dunia kerja kelainan buta warna mempengaruhi penderitanya dalam memilih karir atau pekerjaan. Beberapa pilihan pekerjaan mensyaratkan karyawannya tidak memiliki kelainan buta warna.

Tes Farnsworth Munsell adalah metode untuk melihat kemampuan seseorang menyusun kecerahan warna. Tes ini dapat membedakan tipe defisiensi penglihatan warna dan mengevaluasi tingkat keparahan diskriminasi warna. Tes Farnsworth Munsell memberikan kode yang unik setiap warna berdasarkan tiga karakteristik yaitu hue, value, dan chroma. Hue mengacu pada warna panjang gelombang dominan, value mengacu cahaya relatif, dan chroma mengacu saturasi warna. Metode tes Farnsworth Munsell dapat menguji buta warna dengan lebih detail dan memberikan akurasi hasil dengan tingkat yang lebih tinggi. Farnsworth Munsell bisa melakukan skrining atau deteksi kelemahan warna tertentu, seperti kelemahan terhadap warna merah, kelemahan terhadap warna hijau, dan kelemahan terhadap warna biru.

Dengan masalah demikian, tujuan dan manfaat yang peneliti harapkan adalah mencoba mencari alternatif penggunaan metode tes buta warna Farnsworth-Munsell dengan membuat atau membangun sistem tes buta warna FarnsworthMunsell ke dalam bentuk aplikasi mobile berbasis Android. Dengan aplikasi tes buta warna tersebut maka masyarakat dapat dengan mudah melakukan tes buta warna hanya dengan smartphone berbasis Android. Penulis memilih mengembangkan aplikasi berbasis Android karena saat ini mayoritas masyarakat umumnya menggunakan smartphone berbasis Android.

\section{LANDASAN TEORI}

\section{A. Buta Warna}

Buta warna merupakan kelainan pada mata yang tidak dapat membedakan warna. Buta warna adalah suatu keadaan dimana seseorang tidak dapat membedakan warna tertentu yang bisa dibedakan oleh orang dengan mata normal. Seseorang yang menderita buta warna dapat disebabkan oleh kelainan sejak lahir atau akibat penggunaan obat-obatan yang berlebihan. Buta warna umumnya diderita oleh laki-laki, sedangkan wanita hanyalah sebagai gen pembawa/resesif [1].

Pada kondisi normal, sel kerucut di retina mata mempunyai spektrum terhadap tiga warna dasar, yaitu warna merah, hijau, dan biru. Pada orang yang mempunyai sel-sel kerucut sensitif untuk tiga jenis warna ini, maka ia dikatakan normal. Pada orang tertentu, mungkin hanya ada dua atau bahkan satu atau tidak ada sel kerucut yang sensitif terhadap warna-warna tersebut. Pada kasus ini disebut dengan buta warna. Jadi buta warna biasanya menyangkut warna merah, biru, atau hijau. Orang tersebut biasanya tidak buta semua warna melainkan warna-warna tertentu saja [2].

1. Klasifikasi Buta Warna

Tingkatan buta warna dapat diklasifikasikan menjadi 3 jenis yaitu [3]:

1) Anomali Trikomat: Suatu keadaan dimana tiga jenis sel kerucut tetap ada, tetapi satu diantaranya tidak normal atau tidak berfungsi dengan baik, sehingga penderita akan mengalami kesulitan membedakan nuansa warna tertentu. Jenis buta warna ini sering dialami yaitu:

a) Protanomali (lemah merah) Terjadi karena sel kerucut warna merah tidak berfungsi dengan baik, sehingga penderita kurang sensitif atau kesulitan mengenali warna merah dan perpaduannya.

b) Deuteranomali (lemah hijau) Terjadi karena sel kerucut warna hijau tidak berfungsi dengan baik, sehingga penderita kurang sensitif atau kesulitan mengenali warna merah dan perpaduannya.

c) Tritanomali (lemah biru) Terjadi karena sel kerucut warna biru tidak berfungsi dengan baik, sehingga penderita kurang sensitif atau kesulitan mengenali warna merah dan perpaduannya.

2) Dikhromat: keadaan ketika satu dari tiga sel kerucut tidak ada. Ada tiga klasifikasi dikromasi yaitu:

a) Protanopia (buta warna merah). Protanopia terjadi karena sel kerucut warna merah tidak ada sehingga tingkat kecerahan warna merah menjadi berkurang.

b) Deuteranopia (buta warna hijau). Deuteranopia terjadi karena sel kerucut warna hijau tidak ada sehingga tingkat kecerahan warna hijau atau perpaduannya menjadi berkurang.

c) Tritanopia (buta warna biru). Tritanopia terjadi karena sel kerucut warna biru tidak ada sehingga tingkat kecerahan warna biru atau perpaduannya menjadi berkurang.

3) Monokhromat: Monokromasi adalah kondisi retina mata yang mengalami 
kerusakan total dalam merespon warna. Monokromasi ditandai dengan hilangnya atau berkurangnya semua penglihatan warna, sehingga yang terlihat hanya putih dan hitam yang mampu diterima retina. Jenis buta warna ini prevalensinya sangat jarang.

\section{B. Defenisi Tes}

Tes merupakan salah satu upaya pengukuran terencana yang digunakan oleh guru untuk mencoba menciptakan kesempatan bagi siswa memperlihatkan prestasi mereka dalam yang berkaitan dengan tujuan yang telah ditentukan [4].

\section{Tes Buta Warna}

Tes buta warna adalah suatu tes yang digunakan untuk mengetahui seseorang mengalami buta warna atau tidak [5].

Beberapa tes buta warna yang bisa dilakukan untuk mendiagnosa kelainan penglihatan ini antara lain adalah:

1) Tes Ishihara

2) Tes warna Cambridge

3) Tes penyusunan

4) Anomaloscope

5) Tes lentera Farnsworth

6) Tes Farnsworth-Munsell

\section{Metode Farnsworth Munsell}

Farnsworth Munsell adalah sistem uji penglihatan manusia yang sering digunakan untuk menguji buta warna [6].

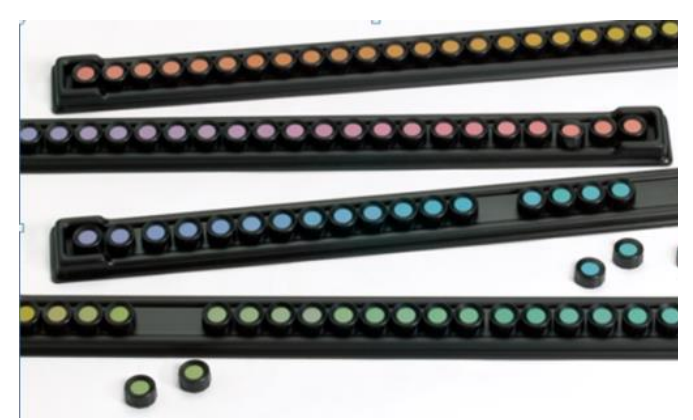

Gambar 2.1. Alat Tes Farnsworth Munsell

Tes Farnsworth-Munsell menggunakan banyak lingkaran dengan berbagai gradasi dari warna yang sama, sama seperti tes penyusunan. Tes ini dilakukan untuk memeriksa apakah pasien dapat membedakan perubahan warna yang sangat tipis.

Mereka yang menderita buta warna sejak lahir tidak akan mengalami kehilangan penglihatan tambahan atau kebutaan total. Tetapi karena sel-sel kerucut yang tersusun di dalam lapisan retina mata juga digunakan untuk melihat detail kecil, penderita buta warna cenderung memiliki visi atau penglihatan yang kurang tajam. Kacamata dengan lensa warna (tinted eyeglasses) bisa membantu penderita buta warna melihat dengan lebih baik.

E. Definisi Aplikasi

Aplikasi adalah Program siap pakai yang dapat digunakan untuk menjalankan printahprintah dari pengguna aplikasi tersebut dengan tujuan mendapatkan hasil yang lebih akurat sesuai dengan tujuan pembuatan aplikasi tersebut [7].

F. Android

Android merupakan salah satu system operasi yang sangat berkembang saat ini, dengan berbasiskan Linux system operasi ini dirancang untuk mengembangkan perangkat seluler layar sentuh seperti smartphone dan juga komputer tablet. Android menyediakan platform terbuka bagi para pengembang untuk menciptakan aplikasi untuk digunakan oleh bermacam piranti gerak [8].

\section{G. Android Studio}

Android studio adalah IDE (Integrated Development Environment) resmi untuk pengembangan aplikasi Android dan bersifat open source atau gratis. Peluncuran Android Studio ini diumumkan oleh Google pada 16 mei 2013 pada event Google I/O Conference untuk tahun 2013 [9].

\section{H. Unifed Modeling Language}

1) Use Case Diagram

Use Case Diagram adalah diagram yang secara grafis menggambarkan siapa yang akan menggunakan sistem dan dengan cara apa pengguna mengharapkan untuk berinteraksi dengan sistem [10].(pressman)

\section{2) Activity Diagram}

Diagram aktivitas menunjukkan dependensi antara (paralel) kegiatan sebagaimana kita bergerak dari titik awal ke tujuan yang diinginkan. Mereka mirip dengan diagram alir, tradisional digunakan untuk aliran model program atau kegiatan manusia [10]

3) Class Diagram

Bersifat statis, diagram ini memperlihatkan himpunan kelas, antarmuka, kolaborasi, serta relasi. Diagram ini umum dijumpai pada pemodelan sistem berorientasi objek. Meskipun bersifat statis, sering pula diagram kelas memuat kelas aktif [10].

4) Sequence Diagram

Sequence diagram bersifat dinamis, diagram urutan adalah diagram interaksi yang menekankan pada pengiriman pesan (message) dalam suatu waktu tertentu [10] 


\section{Metode Penelitian}

A. Pengumpulan Data

Metode Pengumpulan Data merupakan teknik atau cara yang dilakukan untuk mengumpulkan data. Pada penelitian ini peneliti menerapkan metode Observasi dan Studi Pustaka dalam pengumpulan data.

1. Metode Wawancara, peneliti akan melakukan wawancara kepada ahli penyakit mata di RSUD M. Yunus, Jl. Bhayangkara, Sidomulyo, Gading Cempaka, Kota Bengkulu, 38211.

2. Metode Observasi, peneliti akan melakukan observasi pada media infromasi seperti Internet, majalah dan artikel kesehatan.

3. Metode studi pustaka, peneliti akan mengumpulkan data dari buku, jurnal, dan sumber penelitian sebelumnya yang berkaitan dengan penelitian ini.

\section{B. Model Pengembangan Sistem}

Dalam penelitian ini pengembangan sistem ini dilakukan dengan menggunakan model incremental, incremental dalam rekayasa perangkat lunak menerapkan rekayasa perangkat lunak perbagian, hingga menghasilkan perangkat lunak yang lengkap. Proses pembangunan berhenti jika produk telah mencapai seluruh fungsi yang diharapkan. Model ini terdiri dari proses analisis, desain, kode dan pengujian/testing.

\section{Design}

1) UML (Unifed Modeling Language)

a) Use Case Diagram

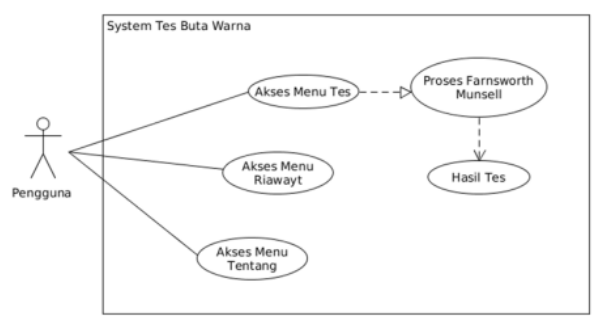

Gambar 3.1. Use Case Diagram

b) Activity Diagram

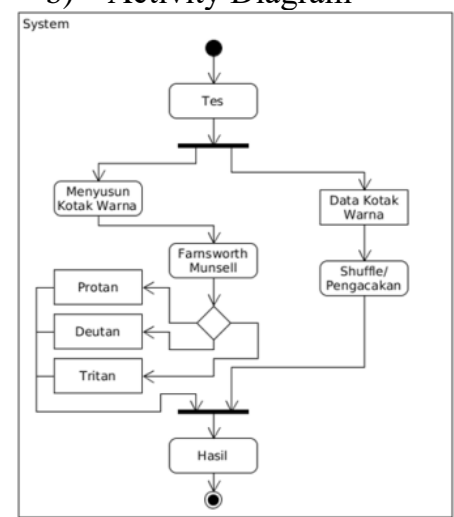

Gambar 3.2. Activity Diagram c) Class Diagram
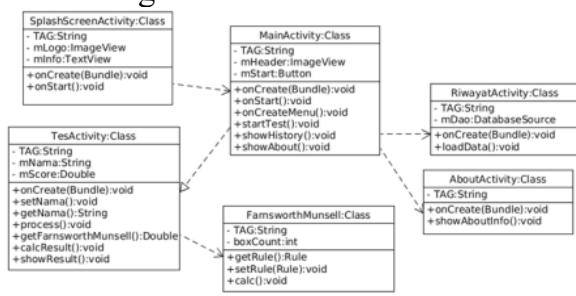

Gambar 3.3 Class Diagram

d) Sequence Diagram

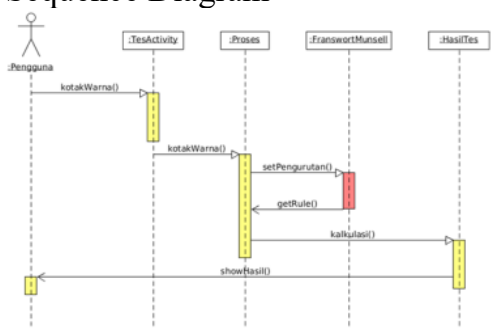

Gambar 3.4. Sequence Diagram

2) Input dan Output

Input atau masukan pada aplikasi yang akan dikembangkan oleh peneliti berupa data yang diperlukan sistem untuk melakukan proses sistem dalam mengolah informasi sesuai dengan yang telah direncanakan. Data yang dimaksud berupa kemampuan pengguna dalam menyusun kotak warna berdasarkan urutan gradiasi warna.

Sedangkan Output atau keluaran pada aplikasi ini yaitu hasil pemprosesan dari data input yang diolah dengan perhitungan metode Farnsworth Munsell dan menghasilkan result berupa penjelasan tingkat buta warna yang dialami pengguna.

3) Design Rancangan

Design rancangan adalah penggambaran, perencanaan dan pembuatan sketsa tampilan aplikasi yang bertujuan untuk memperjelas tahap pembuatan aplikasi yang akan peneliti kembangkan. Berikut merupakan design rancangan aplikasi berbasis Android yang akan peneliti kembangkan: 


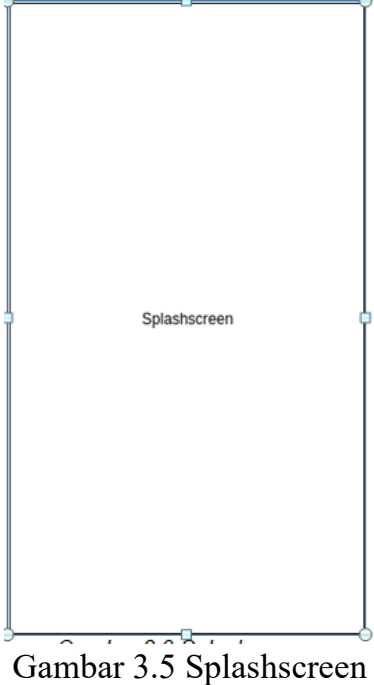

Splashscreen merupakan tampilan penyambut atau tampilan awal aplikasi saat aplikasi di buka atau dijalankan. Pada Splashscreen ini akan menampilkan nama dan info singkat tentang aplikasi dan secara bersamaan terjadi proses load sistem dan persiapan data-data sistem yang berjalan di background.

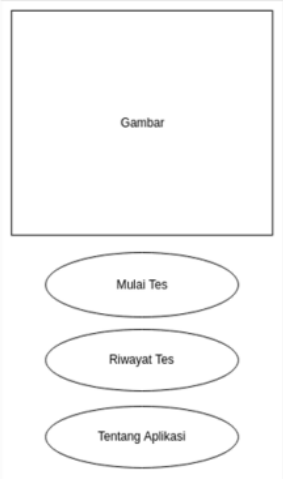

Gambar 3.6 Rancangan Menu Utama

\section{Hasil Dan Pembahasan}

Terdapat tiga jenis buta warna yaitu buta warna Tritan, buta warna deutan dan buta warna ptoran. Buta warna tritan, yaitu seseorang kurang bisa menangkap spektrum warna biru., sensitifitas mata terhadap warna biru kurang. Buta warna deutan, yaitu seseorang kurang bisa menangkap spektrum warna hijau.. Dan buta warna protan, yaitu seseorang kurang bisa menangkap spektrum warna merah. Dalam kata lain, sensitifitas mata terhadap warna merahnya kurang.

Farnsworth Munsell adalah sistem uji penglihatan manusia yang sering digunakan untuk menguji buta warna. Sistem ini dikembangkan oleh Dean Farnsworth pada tahun 1940-an Dibandingkan metode Ishihara, metode Fansworth Munsell dapat melakukan tes yang dapat membedakan jenis buta warna yang dialami.

\section{A. Tampilan Aplikasi Tes Buta Warna}

1) Tampilan Splashscreen

Splashscreen merupakan layar guyuran atau layar tunggu saat sistem memuat data-data kebutuhan aplikasi.

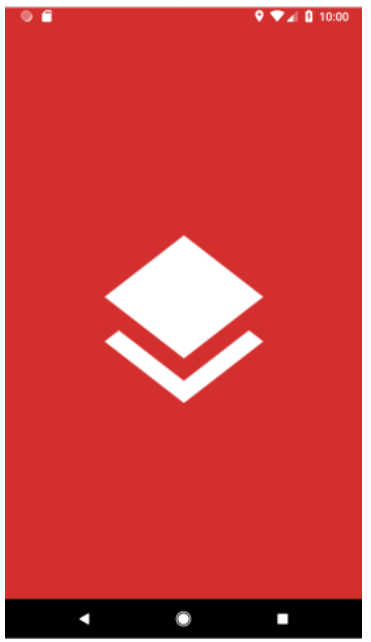

Gambar 4.1. Tampilan splashcreen

\section{2) Tampilan Menu Utama}

Pada menu utama ini terdapat sebuah gambar (ImageView) dan tiga tombol (Button) navigasi menu diantaranya tombol Mulai Tes, tombol Riwayat Tes dan tombol Tentang.
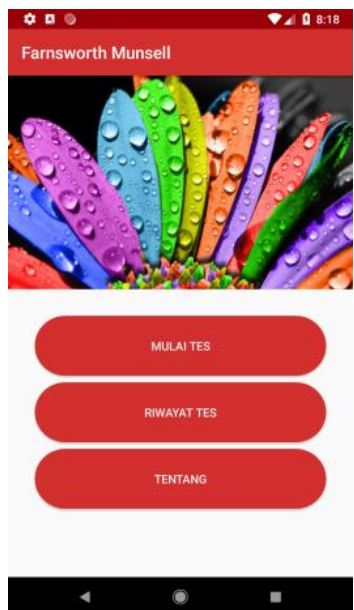

Gambar 4.2. Tampilan Menu Utama

3) Tampilan Memulai Tes

Pada menu ini pengguna harus mengisi kolom inputan nama, jenis kelamin dan usia. Setelah data lengkap, pengguna dapat menekan tombol mulai tes lalu sistem akan menampilkan menu tes. 


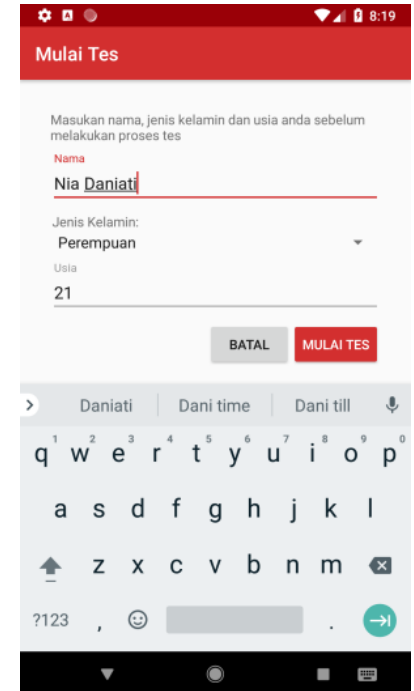

Gambar 4.3. Memulai Tes

4) Menu Tes Buta Warna

Menu tes buta warna merupakan menu inti dari aplikasi tes buta warna ini karena pada menu inilah akan diproses perhitungan metode Farnsworth Munsell dalam menentukan skor error, nilai tritan, nilai deutan dan nilai protan yang dialami pengguna. Pada menu ini terdapat 40 kotak warna gradiasi dapat dilihat pada gambar dibawah ini.

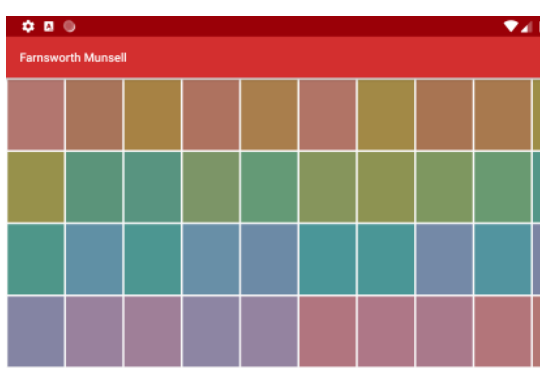

Gambar 4.4. Tes Farnsworth Munsell

Pada gambar diatas kotak warna tersusun secara acak. Pengacakan dilakukan secara otomatis oleh sistem. Setiap tes pengacakan akan selalu menghasilkan posisi kotak warna yang berbeda dari pengacakan sebelumnya atau pun pengacakan berikutnya. Pengacakan kotak warna ini dilakukan dengan memanfaatkan utilitas yang sudah ada dalam bahasa pemrograman Java yaitu method shuffle pada kelas Collections yang digunakan untuk melakukan shuffling atau pengacakan list array.

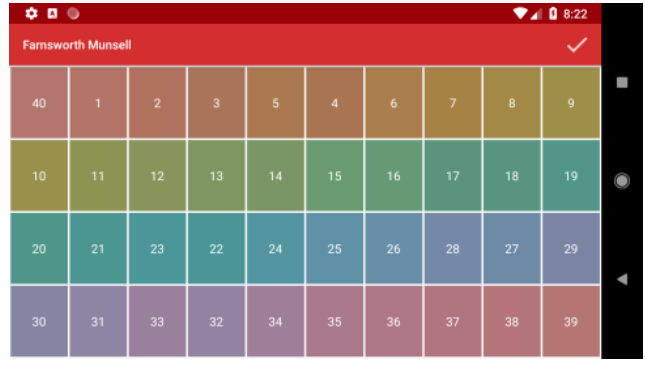

Gambar 4.5 Tampil Indeks Kotak
Warna

Pada gambar diatas angka indeks setiap kotak warna terlihat dan pengguna dapat melihat kesalahan penyusunan urutan kotak warna namun tidak dapat melakukan penyusunan lagi atau memperbaiki urutan masing-masing kotak warna yang salah posisi. Selanjutnya pengguna menekan tombol centang sekali lagi untuk melakukan proses perhitungan nilai hasil pengurutan dengan metode Farnsworth Munsell.

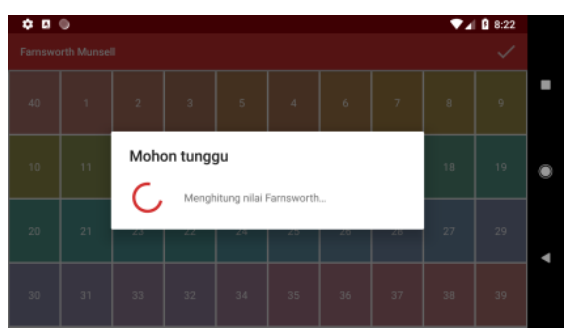

Gambar 4.6. Proses Hitung Hasil

Setelah perhitungan berhasil sistem akan menampilkan hasil yang berupa detail informasi hasil tes beserta berupa teks dan diagram spider seperti gambar dibawah ini.

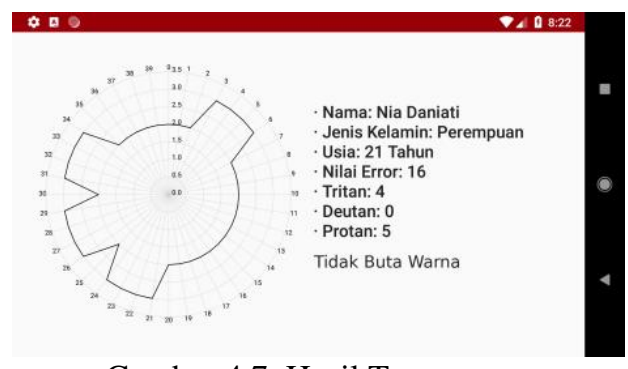

Gambar 4.7. Hasil Tes

Penerapan metode Farnsworth Munsell pada aplikasi tes buta warna yang peneliti kembangkan ini mengacu pada metode perhitungan manual Farnsworth Munsell. Setiap kotak warna memiliki nomor indeks sebagai patokan atau panutan dalam menghitung nilai error dan nilai jenis 
buta warna yang dialami pengguna. Setiap kotak warna memiliki tingkat gradiasi warna yang berbeda-beda. Pada aplikasi yang penulisan kembangkan tesebut, kode warna ditulis dalam bentuk Hex kode sebayak empat puluh kode warna yang berbeda.

\section{B. Pengujian Sistem}

\section{1) Blackbox Testing}

Pengujian sistem dengan teknik pengujian Black Box sepenuhnya valid dan aplikasi dapat berjalan sesuai dengan skenario pengujian.

Table 4.1. Blackbox Testing

\begin{tabular}{|c|c|c|c|}
\hline No. & Skenario Pengujian & Hasil Yang Diharapkan & Kesimpulan \\
\hline 1 & \begin{tabular}{l|}
$\begin{array}{l}\text { Pengujian Start Aplikasi seharusnya } \\
\text { aplikasi dapat berjalan. }\end{array}$ \\
\end{tabular} & \begin{tabular}{|l} 
Aplikasi dapat berjalan menampilkan \\
Splashscreen hingga ke menu utama.
\end{tabular} & Valid \\
\hline 2 & $\begin{array}{l}\text { Pengujian Tombol Navigasi pada } \\
\text { menu utama seharusnya bekerja sesuai } \\
\text { masing-masing fungsi. }\end{array}$ & $\begin{array}{l}\text { Tombol Mulai Tes dapat menampilkan } \\
\text { menu Mulai Tes, Tombol Riwayat Tes } \\
\text { dapa menampilkan menu Riwayat, dan } \\
\text { Tombol Tentang dapat menampilkan } \\
\text { infromasi tentang aplikasi. }\end{array}$ & Valid \\
\hline 3 & $\begin{array}{l}\text { Pengujian menu Mulai Tes seharusnya } \\
\text { dapat menghandle input informasi } \\
\text { penggung. }\end{array}$ & 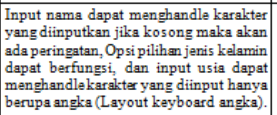 & Valid \\
\hline 4 & 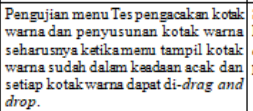 & $\begin{array}{l}\text { Setiap kotak warna teracalk saat pertams } \\
\text { kali tampil dan dapat dilakukan draga and } \\
\text { drop dan pengegna dapat melakukan } \\
\text { penyusunan kotalk warma. }\end{array}$ & Valid \\
\hline 5 & 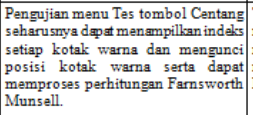 & $\begin{array}{l}\text { Tombol Centang pada menu Tes dapat } \\
\text { menampilkan indeks kotak warna dan } \\
\text { mengunci posisi kotak wamn dan dapat } \\
\text { memproses perhintungan Farmsworth } \\
\text { Munsell hingem menuju tampilan hasil tes. }\end{array}$ & Valid \\
\hline 6 & 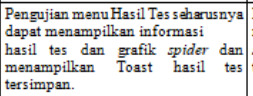 & $\begin{array}{l}\text { Menu hasil tes dapat berjalan dan } \\
\text { menampilkan detail infomasis serta grafik } \\
\text { spider lalu menampilkan Toast hasil tes } \\
\text { tersimpan. }\end{array}$ & Valid \\
\hline 7 & 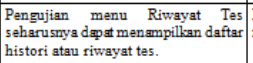 & $\begin{array}{l}\text { Menu Riwayat Tas dapat berjalan dan } \\
\text { menampilkan daftar histori hasil tes. }\end{array}$ & Valid \\
\hline 8 & \begin{tabular}{|l|} 
Pengujian opsi hapus riwayat pada \\
menu Riwayat Tes seharusyya dapat \\
menghapus item pada histori.
\end{tabular} & $\begin{array}{l}\begin{array}{l}\text { Opsi hapus pada manu Riwayat Tes dapat } \\
\text { menghapus item histori. }\end{array} \\
\text { ings }\end{array}$ & Valid \\
\hline 9 & \begin{tabular}{|l|}
$\begin{array}{l}\text { Pengujian tampilan informasi tentang } \\
\text { seharusnya dapt menampilkan } \\
\text { informasi tentang aplikasi. }\end{array}$ \\
\end{tabular} & $\begin{array}{l}\text { Informasi tentang aplikasi dapat tampil } \\
\text { pada tampilan tentang. }\end{array}$ & Valid \\
\hline
\end{tabular}

\section{2) Whitebox Testing}

Menguji sistem pada struktur kontrol secara prosedural menggambarkan kode program kedalam graph (node dan edge).

a) Kode Program data Kotak Warna dan Pengacakan.

Berikut ini merupakan kode untuk mempopulasikan data kotak warna sekaligus proses pengacakan kotak warna.

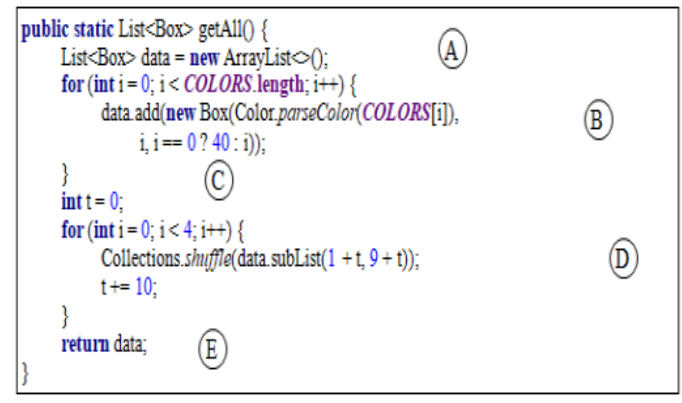

b) Flow Graph data Kotak Warna dan Pengacakan.

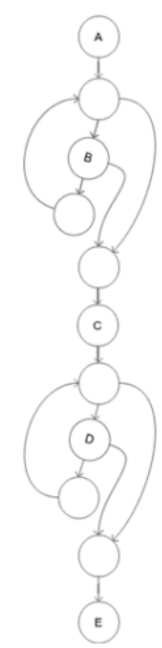

Gambar 4.6 Flow Graph data Kotak Warna dan Pengacakan

c) Kode Program Metode Farnsworth Munsell

int [ $\mathrm{val}=$ new int [mBoxes .size 0$]$

$\operatorname{val}[0]=0$;

or (int $i=0 ; i<$ val length $-2 ; i++)$

int valLeft $=0$, valRight $=0$;

int left $=$ mBoxes.get $(\mathrm{i})$.position;

int mid $=$ mBoxes $\cdot$ get $(i+1)$ position

int right $=\mathrm{mBoxes} \cdot \operatorname{get}(\mathrm{i}+2) \cdot$ position

if $($ left $>$ mid) valLeft $=$ left - mid;

else if $($ left $<$ mid $)$ valLeft $=$ mid - left

if $($ mid $>$ right $)$ valRight $=$ mid - right

else if (mid < right) valRight = right - mid

val $[i+1]=$ (valLeft + valRight $)-2$

val[val length -1$]=0$;

(F)

Intent intent $=$ new Intent(this, HasilTesActivity.class);

intent.putExtra( $F M, \mathrm{val})$

intent.putExtra(MulaiTesActivity KEY_NAME, new String[] mUser.nama, mUser.jenisKelamin

startActivity(intent); String.value $O\{\mathrm{mU}$ (ser.usia) $\}$ );

mProgressDintog dismiss);

H

finish();
B

(C) 
d) Flow Graph Metode Farnsworth Munsell

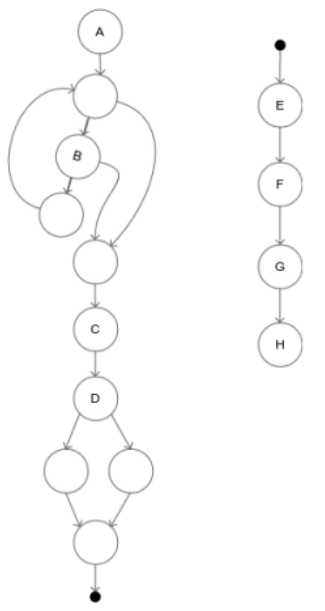

Gambar 4.7. Flow Graph Metode Farnsworth Munsell

\section{3) Pengujian Alpha}

Pengujian Alpha adalah pengujian akhir sebelum perangkat lunak atau aplikasi ini diluncurkan untuk pengguna secara umum. Berikut ini merupakan hasil pengujian Alpha yang telah peneliti lakukan.

Table 4.2 Pengujian Alpha

\begin{tabular}{|c|c|c|}
\hline No. & Pengujian & Ekspektasi \\
\hline 1. & Setup Kotak Warna & $\begin{array}{c}\text { Semua warna pada kotak } \\
\text { warna tersusun sesuai } \\
\text { dengan metode } \\
\text { Famsworth Munsell }\end{array}$ \\
\hline 2. & Implementasi Metode & $\begin{array}{c}\text { Metode Farnsworth } \\
\text { Munsell menghasilkan } \\
\text { perhintungan yang sesuai } \\
\text { dengan hitungan manual }\end{array}$ \\
\hline 3. & Akurasi Sistem & $\begin{array}{c}\text { Aplikasi dapat menghitung } \\
\text { nilai-nilai metode sesuai } \\
\text { kebutuhan sistem }\end{array}$ \\
\hline 4. & Result Sistem & $\begin{array}{c}\text { Aplikasi menghasilkan } \\
\text { output sesuai dengan } \\
\text { perancangan dan } \\
\text { perencanaan sistem }\end{array}$ \\
\hline 5. & Stabilitas Sistem & $\begin{array}{c}\text { Aplikasi dapat berjalan } \\
\text { dengan baik pada } \\
\text { perangkat Android dengan } \\
\text { minimum versi OS } \\
\text { Android 4.4 (KitKat) }\end{array}$ \\
\hline
\end{tabular}

\section{Kesimpulan Dan Saran}

\section{A. Kesimpulan}

1. Aplikasi tes buta warna menggunakan metode Farnsworth Munsell ini dapat berjalan dengan baik dan sesuai dengan perancangan sistem yang telah direncanakan.

2. Penerapan metode Farnsworth Munsell dapat menampilkan hasil tes berupa skor error dan tingkat buta warna yang meliputi Tritanomali, Deuteranomali dan Protanomali.

3. Berdasaran hasil pengujian aplikasi dapat menjalankan fungsi sistem dan melakukan perhitungan skor sesuai dengan perhitugan metode Farnsworth Munsell secara manual dengan baik.
4. Aplikasi tes buta warna menggunakan metode Farnsworth Munsell ini dapat mempermudah perhitungan skor error secara otomatis sehingga mempermudah pengguna dalam mendapatkan hasil tes.

\section{B. Saran}

Dari kesimpulan diatas, ada beberapa saran agar dapat menggunakan program aplikasi ini dengan maksimal.

1. Aplikasi tes buta warna menggambarkan metode Farnsworth Munsell ini memiliki tampilan sederhana dan belum terlalu baik untuk pola UX (User Experience). Diharapkan pengembang selanjutnya dapat membuat tampilan aplikasi ini lebih baik dan lebih mudah digunakan.

2. Perkembangan teknologi akan terus terjadi tentunya dimasa depan aplikasi tes buta warna ini akan usang dan perlu pembaharuan dari segi sistem dan basis pengetahuan.

3. Diharapkan aplikasi ini dapat dikembangkan juga untuk perangkat mobile dengan sistem operasi berbeda (Selain Android) misalnya iOS, Symbian, Windows Phone dan sistem operasi mobile lainnya..

\section{DAFTAR PUSTAKA}

[1] KURNIA, Rahmadi. Penentuan tingkat buta warna berbasis his pada citra ishihara. In: Seminar Nasional Aplikasi Teknologi Informasi (SNATI). 2009.

[2] PURNAMASARI, Prasetya, et al. Tes Buta Warna Metode Ishihara Berbasis Komputer (Kelas XI Jurusan Teknik Instalasi Tenaga Listrik SMK Negeri 3 Semarang). 2015. PhD Thesis. UNIVERSITAS NEGERI SEMARANG.

[3] DHIKA, Randy Viyata; ERNAWATI, Ernawati; ANDRESWARI, Desi. Aplikasi Tes Buta Warna Dengan Metode Ishihara Pada Smartphone Android. Pseudocode, 2014, 1.1: 51-59.

[4] WULAN, Ana Ratna. Pengertian dan esensi konsep evaluasi, asesmen, tes, dan pengukuran. Jurnal, FPMIPA Universitas Pendidikan Indonesia, 2007.

[5] KURNIADI, Dede; FAUZI, M. Mesa; MULYANI, Asri. Aplikasi Simulasi Tes Buta Warna Berbasis Android Menggunakan Metode Ishihara. Jurnal Algoritma, 2016, 13.2: 451-456.

[6] Herman, H. 2007. Majalah Kedokteran Damianus FK Unika Atmajaya.

[7] ABDURAHMAN, Hasan; RISWAYA, Asep Ririh Aplikasi Pinjaman Pembayaran Secara Kredit Pada Bank Yudha Bhakti. Jurnal Computech \& Bisnis, 2014, 8.2: 61-69.

[8] WIJAYA, Ardi. Pembuatan Aplikasi Panggilan Darurat Berbasis Android Menggunakan Location Based Services. Journal Scientific and Applied Informatics, 2019, 2.1: 278315.

[9] JUANSYAH, Andi. Pembangunan aplikasi child tracker berbasis assisted-global positioning system (a-gps) dengan platform android. Jurnal Ilmiah Komputer dan Informatika (KOMPUTA), 2015, 1.1: $1-8$

10 Pressman. (2015). Konsep dasar perancangan sistem berbasis orientasi objek. Yogyakarta: Andi Offset 